\title{
NEW FORMS OF ODONTOPONERA TRANSVERSA
}

\author{
By WM. S. CReightoN
}

Odontoponera was first recognized as a distinct genus in 1862 when Mayr raised to generic rank an ant described a year earlier by Frederick Smith as Ponera denticulata. This insect was later found to be identical with Smith's Ponera transversa described in 1857. The name denticulata was, therefore, replaced by transversa. Although the single species by which this genus is represented is fairly abundant and distributed throughout many of the islands of the East Indies and the adjacent portions of the continent, little attention has been paid to its variations. Wheeler and Chapman in 1925 described biconcentrica, a variety from the Philippines but except for this no other form has been noted. Dr. W. M. Wheeler has kindly permitted me to examine the Odontoponera material in his collection and I find that it is possible to recognize two additional variants. One of these is plainly of subspecific rank while the other appears to be a color variety of the typical transversa. Biconcentrica must, I believe, be raised from varietal to subspecific status.

The shape and the sculpture of the node of the petiole which appear at first sight to offer striking characters for separation are quite valueless in this regard. In a series of workers from a single nest the petiole may be narrow with a deeply notched summit and heavy rugæ on the basal half or relatively broad with the notch and rugæ reduced or absent. The same is true to a lesser degree of the sculpture of the pronotum. This usually consists of more or less parallel, heavy, transverse rugæ. Occasionally, however, one or two workers in a series have the posterior pronotal rugæ twisted into two whorl-like configurations. As may be recalled this characteristic formed the basis for the recognition

1Contributions from the Entomological Laboratory of the Bussey Institution, Harvard University, No. 315. 
of biconcentrica. Were this the only distinction the validity of biconcentrica would be extremely doubtful but, as I shall show later, there are other very significant differences by which that form may be separated.

Smith, with his customary predilection for minor details, has noted certain characteristics of color in his original description which permit a rather accurate inference as to the nature of the true transversa. I have chosen to regard as typical a form which occurs in southern China, Indochina, Burma, the Phillipines, Borneo and Java. This insect shows the piceous body and ferrugineous appendages mentioned by Smith. Furthermore its distribution is considerably more extensive than that of any of the other forms and it seems logical to suppose that it would be the first to be taken. The distribution of the remaining variants is much more restricted. The range of nitens (subsp. nov.) extends from Borneo through Java and Sumatra to Singapore. Infuscata (var. nov) is known only from Java and one of the Sunda Islands. The distribution of biconcentrica appears to be more northern. It occurs in China and the Philippines but the material is so scarce that its range is largely a matter of speculation.

The following key may facilitate the separation of the various forms :

1. Posterior angles of the enipotum each armed with one or two acute short teeth, the subpetiolar lamella feebly pilose, the rugæ strongly shining subsp. nitens

Posterior angles of the epinotum each armed with a divergent series of three or four broad, coarse teeth, the subpetiolar lamella strongly pilose, the rugæ opaque or subopaque

2. Head one-fifth longer than broad, the sides approximately parallel; color dull yellow, the abdomen brownish .............................................subsp. biconcentrica

Head as broad as long, the sides feebly convex, color black, the appendages ferrugineous or brownish black 
3. Mandibles, clypeus and appendages ferrugineous

transversa

Mandibles, clypeus and appendages blackish brown var. infuscata

Odontoponera transversa (Fred. Smith)

O. transversa, (F. Smith), Jour. Proc. Linn. Soc. Lond. Zool. Vol. 2, p. 68 (1857) worker (Ponera).

Ponera transversa, F. Smith, Cat. Hym. Brit. Mus. Vol. 6, p. 86, (1858) worker.

O. transversa, Dalla Torre, Cat. Hym. Vol. 7, p. 30 (1893 ; Forel, Jour. Bombay Nat. Soc. Vol. 13, p. 314, Hist. (1900) worker; Bingham, Fuana Brit. India, Hym. Vol. 2, p. 73, f. 38, (1903) worker $\%$.

Emery, Gen. Insect. Hym. Ponerinæ, p. 60, (1911) worker o 0 .

Ponera denticulata, F. Smith, Cat. Hym. Brit. Mus. Vol. 6, p. 90. f. 13, 14, (1858) \& ; Roger, Berl. Ent. Zeitschr. Vol. 5, p. 11, (1861) worker.

O. denticulata, Mayr, Verh, Zool-bot. Ges. Wien, Vol. 12, p. 717, (1882).

There have been so many descriptions of O. transversa that another complete account of this easily recognized insect seems entirely superfluous. I shall give only those characteristics which are of use in distinguishing the typical form from the other variants.

Head and thorax piceous, the abdomen usually brownish black with the posterior borders of the segments narrowly edged with brown, rarely the entire abdomen piceous. Mandibles, clypeus, antennæ and legs ferrugineous; coxæ blackish brown. Long hairs moderately abundant, golden; pubescence whitish yellow, very sparse on the rugose portions but abundant elsewhere, particularly long and thick on the subpetiolar lamella. Rugæ coarse, opaque or subopa- 
que, their surfaces, much roughened by numerous small impressions and ridges, cephalic rugæ rougher than those of the thorax. Antennæ with a few shining oval punctures. Head approximately as broad as long, broadest between the posterior fourth and fifth, the sides feebly convex, the occiput broadly and evently concave. Epinotum with two divergent, serrate carinæ consisting of three or four obtuse teeth at the junction of the basal and declivious faces.

The collection contains numerous specimens from southern China and Burma and a few from Indochina. There is a very large amount of material from the Philippines, two workers and a female from northern Borneo and a number of specimens from Java.

Ondontoponera transversa var. infuscata var. nov.

This variety differs from the typical form in the color of the clypeus and the appendages. The mandibles, clypeus, antennæ and legs are blackish brown. The rugæ are in most cases more shining than in the true transversa.

Infuscata appears to be confined to Java and some of the closely adjacent Sunda Islands. A large series of workers taken by L. G. E. Kalshoven in the teak forests of Samarang, Java, may be considered as type material. There are a few specimens taken by N. Gist Gee in Buitenzorg, Java, and others from Mao Marroe, East Soemba (Sunda Islands) collected by Dammerman.

Odontoponera transversa subsp. biconcentrica,

Wheeler \& Chapman.

Odontoponera transversa var. biconcentrica, Wheeler \& Chapman, Philippine Jour. of Sci. Vol. 28, No. 1, (1925) worker.

Biconcentrica was originally separated on the circular configuration of the rugæ of the pronotum but, as has been already shown, the value of this character is lessened since it sometimes occurs in the typical transversa. There are, however, a number of other differences. The head of bicon- 
centrica is approximately one fifth longer than broad with the sides parallel or nearly so, the occipital impression is somewhat feebler and a little more angular than in the true transversa. The color is a peculiar dull, brownish yellow with the abdomen slightly darker. The punctures on the antennal scapes are circular and deeply pigmented which gives the scapes a speckled appearance. The rugæ are smoother and more shining than the typical form but much less so than in the subspecies nitens.

Biconcentrica was described from a single worker taken by Baker on Basilan Island, P. I. There are two others in the collection secured by Sylvestri at Shatin, China. The latter are a trifle smaller and lighter in color than the type but obviously belong to this subspecies.

Odontoponera transversa subsp. nitens subsp. nov.

The rugæ of nitens are finer and much more shining than those of the other forms. The divergent carinæ at the angle of the basal and declivious faces of the epinotum are reduced to one or two small, rather acute teeth. The subpetiolar lamella is feebly pilose, in some specimens virtually bare. As a general rule the node of the petiole is narrower with a more deeply notchd summit than in the other forms but this character cannot be relied upon since the shape of the petiole is highly variable. The color of nitens is quite distinct. The head and thorax vary from ferrugineous to blackish red with the appendages and abdomen brownish red or yellow.

I have designated as types a series of workers collected by E. Mjöberg in North Borneo. I have seen others from Kuching, Borneo, (H. Smith), Depok, Java, (Dammerman), Wai Lima, South Sumatra, (Karny) Dœrian, Riouw Archipelago, (Dammerman), and Singapore, (Baker). 

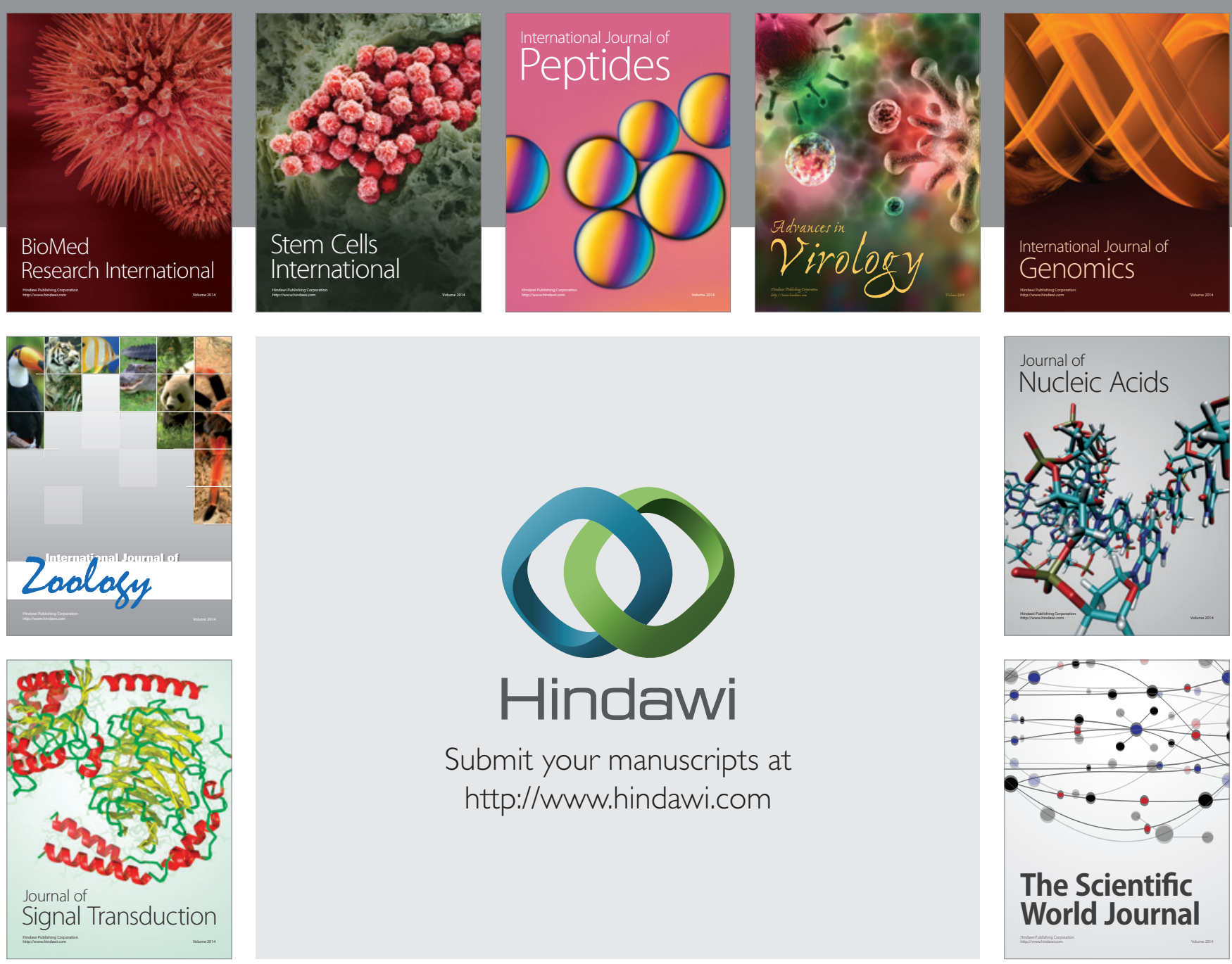

Submit your manuscripts at

http://www.hindawi.com
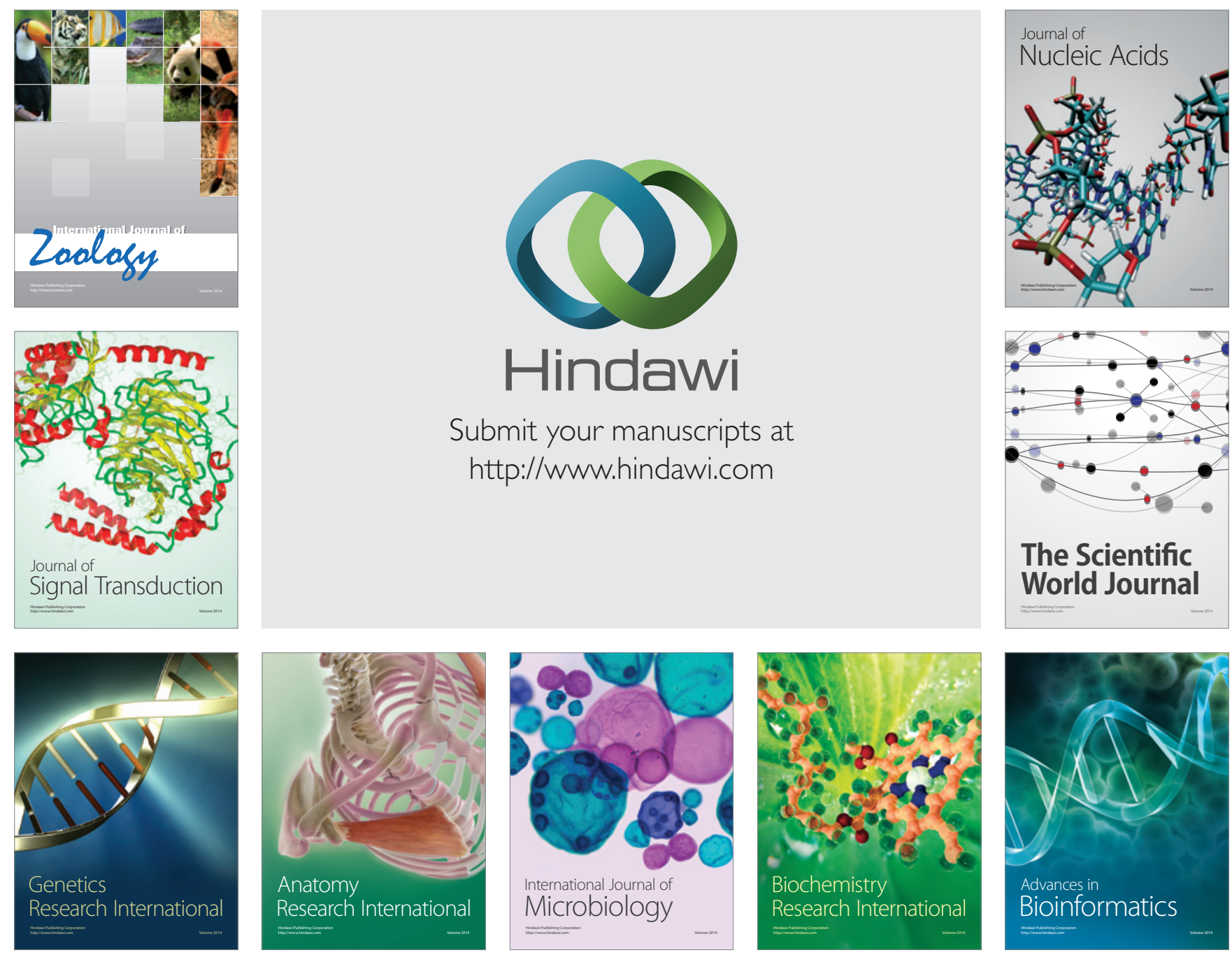

The Scientific World Journal
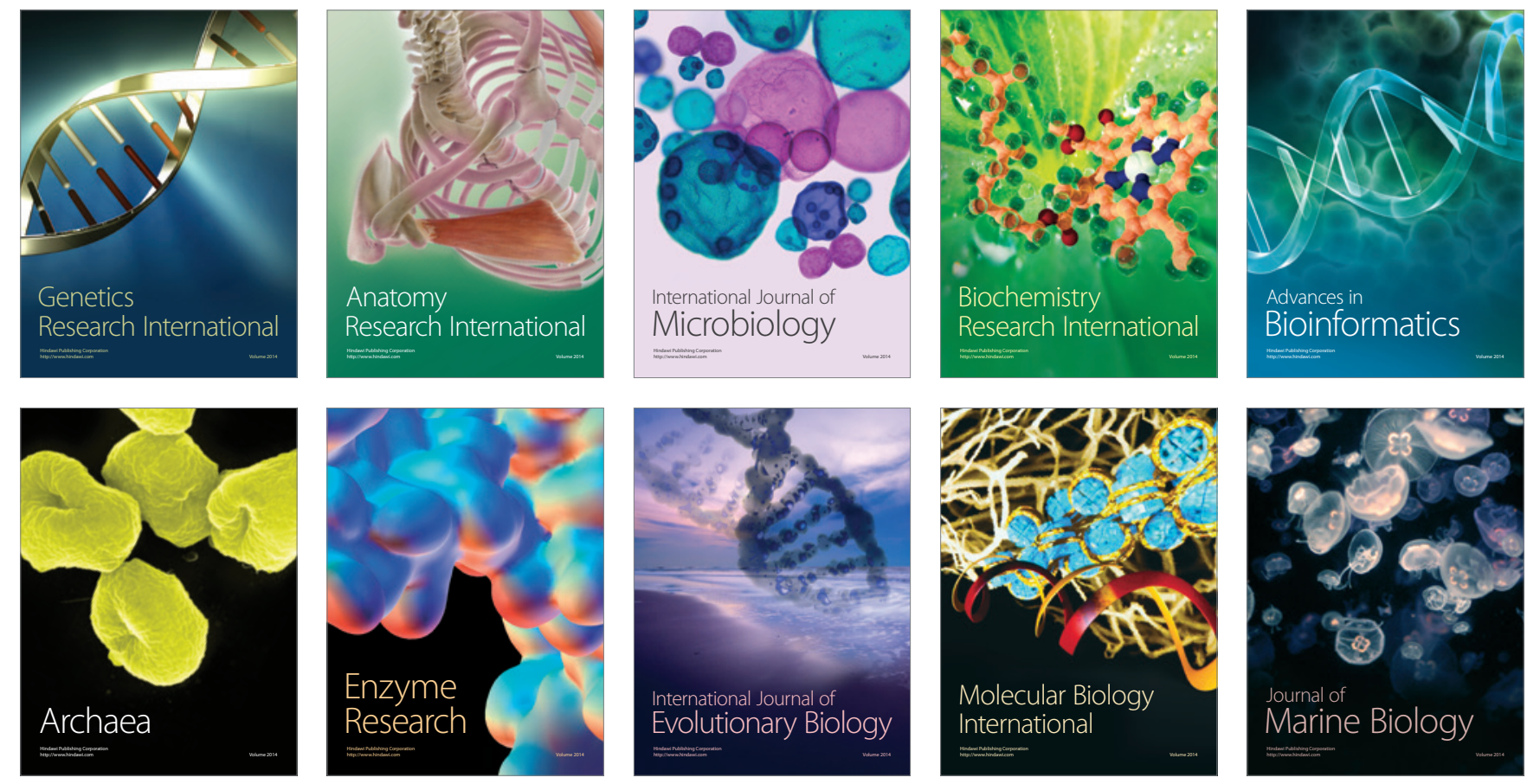